\title{
Heterorhabditis, Steinernema and their bacterial symbionts - lethal pathogens of insects
}

\author{
Ann M. BURnell ${ }^{1, *}$ and S. Patricia STOCK ${ }^{2}$ \\ ${ }^{1}$ Department of Biology, National University of Ireland Maynooth, Maynooth, Co. Kildare, Ireland \\ ${ }^{2}$ Department of Nematology, University of California Davis, CA 95616-8668, USA
}

Presented at the symposium 'Biodiversity in the phylum Nematoda', Gent, Belgium, 17 September 1999

\begin{abstract}
Summary - The entomopathogenic nematodes (EPN) Heterorhabditis and Steinernema together with their symbiont bacteria Photorhabdus and Xenorhabdus, respectively, are obligate and lethal parasites of insects. EPN can provide effective biological control of some important lepidopteran, dipteran and coleopteran pests of commercial crops and they are amenable to large-scale culture in liquid fermentors. They are unique among rhabditids in having a symbiotic relationship with an enteric bacterium species. The bacterial symbiont is required to kill the insect host and to digest the host tissues, thereby providing suitable nutrient conditions for nematode growth and development. This review describes the general biology of EPN and their symbionts and gives an overview of studies to date on EPN biodiversity, biogeography and phylogeny. The impetus for research in EPN and their symbionts has come about because of their biological control potential, with much of the focus in EPN research having been on applied aspects relating to pest control. However EPN and their symbionts are increasingly being viewed as exciting subjects for basic research in the areas of ecology, biodiversity, evolution, biochemistry, symbiosis and molecular genetics. Much progress has been made over the past 20 years in our understanding of the basic biology and genetics of EPN and their symbionts. We are now entering a new phase in which the tools of molecular genetics are being increasingly used to address a range of biological questions in EPN research. The knowledge gained from this endeavour should ensure that EPN will become even more effective biopesticides and should also ensure that EPN and their symbionts gain prominence as unique and intrinsically interesting biological systems.
\end{abstract}

Résumé - Heterorhabditis, Steinernema et leurs symbiotes bactériens - Pathogènes mortels des insectes - Les nématodes entomopathogènes (EPN) Heterorhabditis et Steinernema, avec leur bactéries symbiotes Photorhabdus et Xenorhabdus, respectivement, sont des parasites obligés et mortels des insectes. Les EPN peuvent servir à un contrôle biologique de quelques lépidoptères, diptères et coléoptères importants pour les cultures commerciales et ils sont élevables à grande échelle dans des fermenteurs liquides. Ils sont uniques chez les rhabditides par leur relation symbiotique avec une espèce de bactérie entérique. La bactérie symbiote est nécessaire pour tuer l'insecte hôte et pour digérer les tissus de l'hôte, permettant ainsi des conditons de nutrition favorables à la croissance et au développement du nématode. La présente revue décrit la biologie générale des EPN et de leur symbiotes et donne un état des études actuelles sur la biodiversité, la biogéographie et la phylogénie des EPN. L'impulsion donnée aux recherches sur les EPN et leur symbiotes provient de leur potentialités pour le contrôle biologique, une grande partie des recherches sur les EPN ayant trait à des aspects appliqués en relation avec ce contrôle des parasites. Cependant, les EPN et leur symbiotes bactériens sont de plus en plus considérés comme des sujets intéressants pour la recherche fondamentale dans les domaines de l'écologie, de la biodiversité, de l'évolution, de la biochimie, des processus symbiotiques et de la génétique moléculaire. De nombreux progrès ont été réalisés ces 20 dernières années dans la compréhension de la biologie et de la génétique des EPN et de leur symbiotes. Nous entrons actuellement dans une nouvelle phase où les moyens de la biologie moléculaire sont utilisés de manière croissante pour formuler une série de questions biologiques pour la recherche sur les EPN. Les connaissances résultant de ces efforts doivent conduire à vérifier que les EPN deviendront des biopesticides toujours plus efficaces et que les EPN et leur symbiotes prendront de l'importance en tant que systèmes biologiques uniques et intrinsèquement intéressants.

Keywords - biogeography, entomopathogenic nematode, habitat preference, Photorhabdus, phylogeny, symbiosis, Xenorhabdus.

There are many genera of nematodes that parasitise insects (reviewed by Poinar, 1979), however research on in-

\footnotetext{
* Corresponding author, e-mail: ann.burnell@may.ie
}

sect parasitic nematodes is largely concentrated at present on two families of rhabditid nematodes: the Steinerne- 
matidae Chitwood \& Chitwood, 1937 and the Heterorhabditidae Poinar, 1976. These soil-dwelling nematodes are obligate and lethal parasites of insects and are usually referred to as entomopathogenic nematodes (EPN). EPN can provide effective biological control of some important lepidopteran, dipteran and coleopteran pests of commercial crops and they are amenable to large-scale culture in liquid fermentors. EPN are unique among rhabditids in having a symbiotic relationship with an enteric bacterium species. The bacterial symbiont is required to kill the insect host and to digest the host tissues, thereby providing suitable nutrient conditions for nematode growth and development. Heterorhabditis and Steinernema species have a global distribution (reviewed by Hominick et al., 1996). Species in these genera exhibit differences in host range, infectivity, environmental tolerances and in suitability for commercial production and formulation and this has stimulated many surveys, seeking new strains and species of EPN for biocontrol applications. Thus the number of research publications on this group of nematodes has increased dramatically in recent years and a large number of laboratories world-wide are currently engaged in EPN research.

\section{General biology and life cycle}

The third stage dauer juvenile (DJ) occurs free in the soil and its role is to seek out and infect an insect larva. Steinernema gains entry to the insect larva through natural openings (mouth, anus and spiracles). In addition to these modes of entry, Heterorhabditis also gains entry by abrading the intersegmental membranes of the insect using a dorsal tooth. Once in the haemocoel of the insect the DJ releases cells of a symbiont bacterium that it carries in its intestine. The insect haemolymph provides rich medium for the bacterial cells and these begin to grow, release toxins and exoenzymes and kill the insect. The insect dies rapidly, usually within $24-48 \mathrm{~h}$. The nematodes resume development, moult to the J4 stage and reach adulthood within 2 ( $S$. carpocapsae) or 3 ( $H$. bacteriophora) days when cultured in vivo in larvae of the greater wax moth Galleria mellonella at $23^{\circ} \mathrm{C}$ (Wang \& Bedding, 1996). Nematode reproduction continues over two to three generations until the nutrient status of the cadaver deteriorates whereupon adult development is suppressed and DJ accumulate. These non-feeding infective stages emerge into the soil where they may survive for several months in the absence of a suitable host.
In Steinernema reproduction is amphimictic. Steinernematid DJ mature to become either a male or a female and sex determination appears to be of the XX/XO type, typical of nematodes (Dix et al., 1994). In Heterorhabditis by contrast, the DJ mature to give first generation hermaphrodite females, but these females give rise to a second generation of amphimictic males and females and to self fertile hermaphrodite females and DJ (Dix et al., 1992; Strauch et al., 1994). The male and female karyotypes of Heterorhabditis have not yet been determined, but available data indicate that sexual phenotype is environmentally determined. Wang and Bedding (1996) studied the dynamics of population development of $\mathrm{H}$. bacteriophora and S. carpocapsae in larvae of G. mellonella, after injection into the insect haemocoel of one or two DJ, respectively. Under these conditions three adult generations were produced by both nematode species (Fig. 1). Individual $H$. bacteriophora hermaphrodites laid up to 1000 eggs which developed into second generation males and females, but the first generation hermaphrodites also retained about 500 eggs which developed into DJ via endotokia matricida. Second generation females also laid ca six to ten eggs which developed into another generation of adults, but they also retained another 30 eggs within the nematode body which developed into DJ via endotokia matricida. The third generation females did not oviposit and all of their eggs ( $c a 50$ per female) developed via endotokia matricida into DJ. First and second generation $S$. carpocapsae were found to lay a larger proportion of their eggs than do H. bacteriophora, but all the eggs produced by third generation females developed via endotokia matricida. Unlike $H$. bacteriophora, the juvenile stages resulting from endotokia matricida in S. carpocapsae did not develop into dauer juveniles until they had exited from the body of the mother nematode.

In favourable nutritive conditions in liquid culture second generation Heterorhabditis DJ recover and develop to hermaphrodites (Strauch et al., 1994; Johnigk \& Ehlers, 1999). Strauch et al. (1994) have also shown that when J1 juveniles were starved for $24 \mathrm{~h}$ in Ringer solution $40 \%$ became hermaphrodites, $6.6 \%$ became amphimictic adults and $53 \%$ became DJ. Of the J1 that developed into hermaphrodites $90 \%$ had gone through a pre-dauer J2 stage, which was morphologically distinct from those $\mathrm{J} 2$ growing into amphimictic adults, and $10 \%$ were recovered DJ. These data clearly show the importance of nutritional signals in Heterorhabditis sex determination. The extent to which second generation DJ recover in vivo and resume development has not been determined, nor has the pro- 

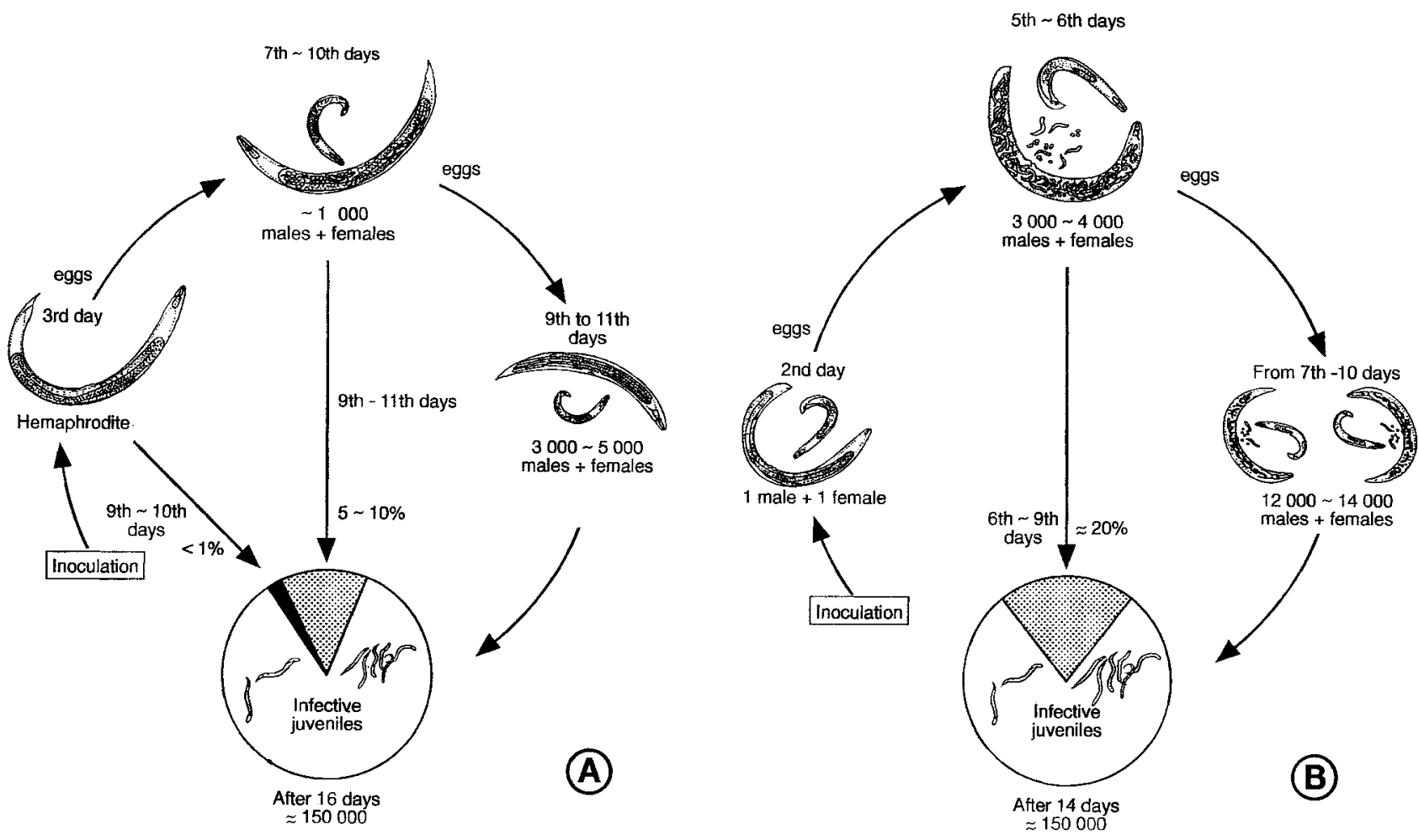

Fig. 1. Population dynamics of A: Heterorhabditis bacteriophora and B: Steinernema carpocapsae $A 24$ in a larva of Galleria mellonella after injecting one or two DJ per insect respectively. The pie charts represent the number of DJ progeny recruited from each generation. ( $\mathbf{(})$ : DJ progeny recruited from first generation females; (1): DJ progeny recruited from second generation females; $(\square)$ : DJ progeny recruited from third generation females (from Wang \& Bedding, 1996).

portion of second generation juveniles which enter the $\mathrm{J} 2$ stage; however Dix et al. (1992) have shown that the early second generation adults which develop in G. mellonella are all amphimictic.

\section{The symbiotic association}

Rhabditid parasites of both vertebrates and invertebrates are considered to have evolved from free living bacterial feeding nematodes (Adamson, 1986). Some rhabditid nematodes have an association with soil invertebrates for which Sudhaus and Schulte (1988) have introduced the term necromency. The DJ of necromenic nematodes enter their host by the body openings or are ingested by the host. The DJ remain quiescent in the host until it eventually dies and its body becomes invaded by saprophytic bacteria. Then the nematode DJ resumes development and growth and reproduction occurs based on the bacteria associated with the decaying cadaver. Sudhaus (1993) has suggested that Heterorhabditis and Steinernema most probably evolved from necromenic nematodes which developed a symbiotic association with an entomopathogenic bacterium. Such a symbiosis specialised for parasitising animals has not been described so far for any other group of nematodes. However the nutritional interactions between EPN and their symbiont bacteria bear many similarities to the ectosymbioses between insects and filamentous fungi (Wilkinson \& Hay, 1997). Symbionts associated with Steinernema are placed in the genus Xenorhabdus (Thomas \& Poinar, 1979) while the bioluminescent symbionts associated with Heterorhabditis are placed in the genus Photorhabdus (Boemare et al., 1993). Symbiont bacteria of both genera are motile and gram-negative and belong to the Enterobacteriaceae. Comparisons of 16S rDNA sequences show that species of Photorhabdus and Xenorhabdus form a phylogenetically coherent cluster that diverged early from the main line of radiation of the Enterobacteriaceae (Forst et al., 1997).

When symbiont bacteria are released by the nematode into the insect haemolymph the bacterial cells begin to 
grow and death of the insect ensues, either from toxaemia or from septicemia, depending on the sensitivity of the insect and the symbiont strain (Forst et al., 1997; Boemare \& Givaudan, 1998). Some strains of Xenorhabdus and Photorhabdus are highly virulent: injection of less than ten cells of the bacterium into the haemocoel may be sufficient to kill a susceptible insect such as $\mathrm{G}$. mellonella or Manduca sexta (Poinar \& Thomas, 1967; Forst et al., 1997, ffrench-Constant \& Bowen, 1999). When cultured in liquid medium, both genera of symbiont bacteria secrete highly virulent insecticidal toxins into the medium (Jarrett et al., 1997; Bowen et al., 1998). As the bacteria enter the stationary phase of their growth cycle they secrete lipase(s), protease(s) and several broad spectrum antibacterial and antifungal antibiotics (reviewed by Akhurst \& Boemare, 1990; Forst \& Nealson, 1996). The likely role for the degradative enzymes is to break down the insect tissues thereby providing a rich food supply for the developing nematode. The insect cadaver containing the rapidly expanding population of nematodes and bacteria retains its shape and does not putrefy, implying a role for the antibiotics produced by symbiont bacteria. However, Jaroz (1996) found relatively low levels of antibiotics in cadavers of G. mellonella infected with $S$. carpocapsae and he postulated that the lack of contamination of insect cadavers resulted from the ability of the symbiont bacteria to out-compete many of the normal gut microflora of the insect host.

Since the majority of EPN bacterial complexes are effective over a wide range of insect orders and the type of humoral and cellular defence reactions of the hosts varies significantly over that range (Akhurst, 1993), it is likely that both the nematodes and the bacteria utilise a variety of pathogenic strategies. Although nematode virulence strategies have received less attention than those of the bacterium, it is known that DJ of $S$. carpocapsae and $H$. bacteriophora release protease secretions which destroy the antibacterial factors of vaccinated $G$. mellonella larvae (Götz et al., 1980; Simoes, 1998). The importance of the symbiotic interaction in the pathogenesis process is clearly seen in the $S$. glaseri/X. poinarii complex. When G. mellonella larvae were injected with either axenic $S$. glaseri or with 1150 cells of $X$. poinarii, the insect larvae survived. However co-injection of 115 $X$. poinarii cells and one $S$. glaseri DJ killed $75 \%$ of the insect larvae (Akhurst, 1986).

Both Xenorhabdus and Photorhabdusoccur in two phenotypic forms. Phase I cells are larger than phase II cells and produce significantly greater amounts of exoenzymes, toxins, antibiotics than phase II forms. However the nematode DJ package and transport only phase I cells. Phase I cells are stored in a special vesicle in the anterior of the intestine in steinernematids (Bird \& Akhurst, 1983) while Heterorhabditis does not have a special vesicle but stores the cells of the symbiont in the anterior of the intestine (Endo \& Nickle, 1991). The role of phase II cells in the symbiotic association is still unclear, as are the molecular mechanisms responsible for this phenomenon.

There are no reports of the isolation of Xenorhabdus and Photorhabdus from soil and it has been generally assumed that these bacteria cannot exist in the soil environment in the absence of their nematode associates. Morgan et al. (1997) released genetically marked strains of $X$. nematophila and $P$. luminescens into non-sterile soil microcosms and they found that the released cells declined to below detection limits within seven days. Although viable colony forming units could not be detected after 7 days, measurement of adenosine triphosphate (ATP) levels suggested that the cells may have entered into a dormant, non-culturable but viable phase. Bleakley and Chen (1999) reported that $P$. luminescens was able to survive and grow over a 30 day period when inoculated into sterilised soil to which nutrient amendments had been added.

\section{Taxonomic status}

The family Steinernematidae Chitwood \& Chitwood, 1937 is currently composed of two genera: Steinernema Travassos, 1927 and Neosteinernema Nguyen \& Smart, 1994. The former genus with 25 species described and the latter with only one species: $N$. longicurvicauda (Table 1). The family Heterorhabditidae Poinar, comprises only one genus, Heterorhabditis Poinar, 1976 with $H$. bacteriophora as the type species and eight other species described (Table 2): however, the taxonomic status of some of these species has been questioned (Adams et al., 1998).

EPN species have mainly been described using the Linnean and biological species concepts and morphological/morphometric criteria and cross-breeding tests have been the most frequently used tools for their identification (Poinar, 1990; Dix et al., 1994; Nguyen \& Smart, 1996; Kaya \& Stock, 1997). Additionally, a number of molecular techniques, including isoenzyme patterns (Akhurst, 1987), total protein patterns (Poinar \& Kozodoi, 1988; Joyce et al., 1994a), RFLP analysis (Curran \& Webster, 1989; Reid \& Hominick, 1993; Joyce et al., 1994b), RAPDs (Gardner et al., 1994; Liu \& Berry, 1995), satellite DNA (Grenier et al., 1996), genomic DNA sequenc- 
Table 1. The genera and species of the family Steinernematidae.

Family Steinernematidae Chitwood \& Chitwood, 1937

= Neoaplectanidae Sbolev, 1953

Type genus: Steinernema Travassos, 1927

Type species: Steinernema kraussei (Steiner, 1923) Travassos, 1927

Other species:

S. abbasi Elawad, Ahmad \& Reid, 1997

S. arenarium (Artyukhovsky, 1967) Wouts, Mráček, Gerdin \& Bedding, 1982

S. affine (Bovien, 1937) Wouts, Mráček, Gerdin \& Bedding, 1982

S. bicornutum Tallosi, Peters \& Ehlers, 1995

S. carpocapsae (Weiser, 1955) Wouts, Mráček, Gerdin \& Bedding, 1982

S. caudatum Xu, Wang \& Li, 1991

S. ceratophorum Jian, Reid and Hunt, 1997

S. cubanum Mráček, Hernandez \& Boemare, 1994

S. feltiae (Filipjev, 1934) Wouts, Mráček, Gerdin \& Bedding, 1982

S. glaseri (Steiner, 1929) Wouts, Mráček, Gerdin \& Bedding, 1982

S. intermedium (Poinar, 1985) Mamiya, 1988

S. karii Waturu, Hunt \& Reid, 1997

S. kushidai Mamiya, 1988

S. longicaudum Shen \& Wang, 1992

S. monticolum Stock, Choo \& Kaya, 1997

S. neocurtillae Nguyen \& Smart, 1992

S. oregonense Liu \& Berry, 1996

S. puertoricense Roman \& Figueroa, 1994

S. rarum (Doucet, 1986) Mamiya, 1988

S. riobrave Cabanillas, Poinar \& Raulston, 1994

S. ritteri de Doucet \& Doucet, 1992

S. scapterisci Nguyen \& Smart, 1992

S. siamkayai Stock, Somsook \& Kaya, 1998

Genus: Neosteinernema Nguyen \& Smart, 1994

Type and only species: Neosteinernema longicurvicauda Nguyen \& Smart, 1994

ing (Liu et al., 1997; Adams et al., 1998), have been used, not only as diagnostic tools, but also to study phylogenetic affinities among EPN. Recently, Adams (1998) proposed that the most suitable species concept for use in nematology is an amalgamation of the phylogenetic and the evolutionary species concepts. Using Heterorhabditis taxa as an example, he delimited species of this genus based on this evolution-based approach.
Table 2. The genera and species of the family Heterorhabditae.

Family Heterorhabditidae Poinar, 1976

Type and only genus: Heterorhabditis Poinar, 1976

Genus Heterorhabditis Poinar, 1976

= Chromonema Khan, Brooks \& Hirschman, 1976

Type species: Heterorhabditis bacteriophora Poinar, 1976

= Chromonema heliothidis Khan, Brooks \& Hirschman, 1976

$=H$. heliothidis (Khan, Brooks \& Hirschman, 1976) Poinar,

Thomas \& Hess, 1977

Other species:

H. argentinensis Stock, 1993

$H$. brevicaudis Liu, 1994

H. hawaiiensis Gardner, Stock \& Kaya, 1994

H. indica Poinar, Karunakar \& David, 1992

H. marelatus Liu \& Berry, 1996

$=H$. hepialius Stock, Strong \& Gardner, 1996

H. megidis Poinar, Jackson \& Klein, 1988

H. poinari Kakulia \& Mikaia, 1997

H. zealandica Poinar, 1990

\section{EPN biodiversity and biogeography}

Hominick et al. (1996) provided a list with the geographic distribution of described EPN species at both continental and national level. Steinernematids have been recorded from all continents except Antarctica (Griffin et al., 1990). Within the genus Steinernema two species, Steinernema carpocapsae and Steinernema feltiae, appear to have a global distribution (Hominick et al., 1996). The other Steinernema species seem to have a more restricted geographic distribution and their occurrence has been recorded only at the continental or national level (Hominick et al., 1996). However, as more surveys are performed, the known range of many species is expected to expand. For instance, Steinernema kraussei originally isolated in the Geggen Mountains, Westphalia, Germany (Steiner, 1923) has subsequently been isolated from other locations in Germany (Mráček et al., 1992; Mráček, 1994), and also from other European countries, such as the Czech Republic, (Mráček, 1977), the Netherlands (Hominick et al., 1995), Switzerland (Steiner, 1994), the United Kingdom (Hominick et al., 1995), and Spain (Garcia del Pino \& Palomo, 1996), suggesting this species has a Palearctic distribution. However, the known geographic range of this species has recently been expanded to include North America (Stock et $a l ., 1999 b)$ thus indicating a Holarctic distribution. Similarly, S. longicaudum, originally isolated in China, has 
recently been recovered in Korea and Western USA, indicating a wider geographic range for this species (Stock $e t$ al., unpubl.).

The situation is somewhat different for heterorhabditids, particularly because fewer species have been described. For instance, H. bacteriophora is currently the widest geographically distributed heterorhabditid, found in all Americas, Southern and Central Europe, Australia and East Asia (China, Japan, Korea). H. indica also has a wide distribution, occurring in the tropics and subtropics, found in southern India, Sri Lanka, peninsular Malaysia, Indonesia, North Australia, the Caribbean region, Egypt, Kenya and in subtropical and warm temperate zones in Japan. In contrast, $H$. zealandica, and $H$. marelatus appear to be species with a more restricted geographic distribution having been found only, respectively, in New Zealand (Akhurst, 1987) and in Oregon and California, USA (Liu \& Berry, 1996a; Stock et al., 1997). The summary presented in Tables 1 and 2 indicates that the diversity of steinernematids is greater than that of heterorhabditids. This is also reflected in the DNA relatedness studies discussed in the next section.

Although a number of surveys have documented habitat preference of EPN, there are at present insufficient and contradictory data to test for correlations (Hominick et al., 1996). However, several authors (Steiner, 1994; Hominick et al.,1995; Stock et al., 1999; Sturhan, 1999) have observed that some Steinernema species are associated with specific habitat types. For example, S. feltiae, S. affine and $S$. intermedium have been found mainly in grassland ecosystems (Boag et al., 1992; Hominick et al., 1995; Stock et al., 1999). Other Steinernema species, by contrast, seem to have a wider habitat range. For instance, $S$. kraussei has been found in coniferous and deciduous forests (Mráček et al., 1999; Steiner, 1994; Stock et al., 2000) and also in grasslands (Sturhan, 1999). These habitat preferences may reflect not only the distribution of suitable insect hosts, but also physiological and behavioural needs that require specific niches (Kaya \& Gaugler, 1993; Hominick et al., 1996).

With respect to Heterorhabditidae, information on habitat specificity widely indicates that some species of this family are prevalent in coastal sandy soils (Griffin et al., 1994; Yoshida et al., 1998; Stock et al., 1999). However, other surveys have indicated that $H$. bacteriophora can be found and is widely distributed in turf and weedy habitats (Stuart \& Gaugler, 1994, Stock et al., 1996). Additionally, Griffin et al. (1999) found that the Irish type of Heterorhabditis, which is restricted to the coastal regions of Ireland and Britain, also occurs in grasslands of Central and Northern Europe.

In all these correlations and associations with habitat, it is important to bear in mind that factors such as sampling size, seasonality and spatial distribution should be taken into account when recording and interpreting data. Another critical aspect that needs to be carefully considered is the correct identification of the isolates which may require the combination of different methods (morphology, cross-hybridisation, molecular techniques) to avoid erroneous assumptions. Restriction digestion of DNA amplified by the polymerase chain reaction (PCR) from the rDNA ITS spacer region is a very convenient and reliable means of sorting new unidentified isolates into species groups. This technique is not difficult to set up in an ecology laboratory and diagnostic restriction profiles of several Heterorhabditis and Steinernema species have been published (Joyce et al., 1994b; Reid et al., 1997). Sufficient material for PCR amplification can be obtained from a single infective juvenile or young adult and it is not necessary to carry out a DNA extraction. A clear and comprehensive description of the protocols for the molecular characterisation of EPN via RFLP analysis of the rDNA ITS region is given in Hominick et al. (1997). Protocols for determining biological species by cross-breeding are given in Poinar (1967) and Akhurst and Bedding (1978) for Steinernema spp. and in Dix et al. (1992) for Heterorhabditis spp.

Five species of Xenorhabdus have been described (see Table 3). Three of these bacterial species are associated with a single species of Steinernema but $X$. bovienii is associated with four (Akhurst \& Boemare, 1988; FischerLe Saux et al., 1999a) and X. poinarii with two nematode species (Fischer-Le Saux et al., 1999a). The genus Photorhabdus consists mostly of the bacterial symbionts of Heterorhabditis as well as some non-symbiotic clinical isolates from human wounds (Farmer et al., 1989). Sequence analysis of the 16S rDNA gene of 40 strains of $P$. luminescens including four clinical samples, indicated that $P$. luminescens was a heterogeneous group and also showed that the clinical samples formed a closely related sub-cluster (Szallas et al., 1997). Fisher-Le Saux et al. (1999b) have recently revised the taxonomy of the genus Photorhabdus and proposed the creation of two new species, $P$. temperata and $P$. asymbiotica, and, further, that $P$. luminescens be divided into three subspecies. An interesting question yet to be addressed is the frequency of co-speciation between the nematode hosts and their 
Table 3. Described species of bacterial symbionts of entomophathogenic nematodes.

Genus: Xenorhabdus Thomas \& Poinar, 1979

Type species: Xenorhabdus nematophila (Thomas \& Poinar, 1979) Akhurst \& Boemare, 1988

Other species:

X. pionarii Akhurst \& Boemare, 1988

X. bovienii Akhurst \& Boemare, 1988

X. beddingii Akhurst \& Boemare, 1988

X. japonica Nishimura, Hagiwara, Suzuki \& Yamanaka, 1994

Genus: Photorhabdus Boemare, Akhurst \& Mourant, 1993

Type species: Photorhabdus luminescens (Thomas and Poinar, 1979) Boemare, Akhurst \& Mourant, 1993

P. luminescens luminescens Fischer-Le Saux, Viallard, Brunel, Normand \& Boemare, 1999

P. luminescens akhurstii Fischer-Le Saux, Viallard, Brunel, Normand \& Boemare, 1999

P. luminescens laumondii Fischer-Le Saux, Viallard, Brunel, Normand \& Boemare, 1999

P. temperata temperata Fischer-Le Saux, Viallard, Brunel, Normand \& Boemare, 1999

Other species:

P. temperata Fischer-Le Saux, Viallard, Brunel, Normand \& Boemare, 1999

P. asymbiotica Fischer-Le Saux, Viallard, Brunel,

Normand \& Boemare, 1999

symbiont bacteria and the extent of horizontal and vertical transfer of the symbiont among the nematode lineages.

\section{Phylogenetic studies of EPN}

The evolutionary relationships of EPN were outlined for the first time by Poinar (1981) in his book The natural history of nematodes, where he speculated that Steinernematidae and Heterorhabditidae arose as two separate lineages, at roughly the same time in the mid-Palaeozoic, some 375 million years ago. He also indicated that similarities in their morphology, life cycles and bacterial symbiosis can be attributed to convergent evolution. Sudhaus (1993) also concluded that the similarities between Heterorhabditis and Steinernema are based on symplesiomorphic characters and convergence.Poinar (1993) suggested potential ancestors for both families based on a literature compilation of morphological, biological, physiological and distributional evidence. Examining similarities of the buccal capsule and male tail morphology, Poinar sug- gested that heterorhabditids evolved from a 'Pellioditislike ancestor' in an arenicolous marine environment, and that steinernematids evolved from a 'proto-Rhabditonema ancestor' in a terrestrial environment.

Several approaches, both from the molecular and morphological perspectives, have been used to study the evolutionary relationships of EPN. Reid (1994) and Reid et al. (1997) studied phylogenetic relationships of Steinernematidae and Heterorhabditidae based on RFLP analysis of the rDNA repeat unit. For this study, 26 isolates representing 11 Steinernema and three Heterorhabditis species were considered. Additionally, two rhabditoids, Caenorhabditiselegans and Phasmarhabditis sp. were included for outgroup comparisons. The relationships between Steinernema species determined by restriction mapping, mirrored (in general terms) those for the morphological data. For example, $S$. arenarium and $S$. glaseri, two morphologically and biologically similar species, were clustered together. This analysis also showed a close relationship between $S$. carpocapsae and $S$. scapterisci, which was originally referred to as the Uruguay strain of $S$. carpocapsae (Nguyen \& Smart, 1988). Reid et al. (1994) also showed that members of the family Heterorhabditidae were more closely related to one another than was the case with members of the Steinernematidae, the latter group being much more heterogeneous. This study also showed that the heterorhabditid and steinernematid genera investigated were more closely related to each other than to the two other rhabditoids used for outgroup comparisons.

Other approaches have included either combined analyses of morphological and RAPD fragments (Liu \& Berry, 1996b), or nucleotide sequence analyses of various rDNA regions such as the $18 \mathrm{~S}$ rDNA sequences (Liu et al., 1997), the ITS-1 spacer region (Adams et al., 1998) and also the ND4 sequences of mitochondrialDNA (Liu et al., 1999). Liu et al. (1997) inferred phylogenetic relationships among both families of EPN using sequence data from part of the 18S rDNA gene. Seventeen isolates of EPN (12 described and five undescribed species) and six Rhabditidae taxa that included Rhabditellaaxei, Rhabditis spp. and four Caenorhabditis species. As in Reid's (1994) study, Liu et al. (1997) also found that steinernematids had more sequence divergence than heterorhabditids. This observation agreed with the documented morphological, biological and distributional evidence. Although the relationships of several Steinernema and Heterorhabditis species were not well supported in their cladistic analysis, final interpretation of their phylogenetic study indicated 
that Steinernematidae and Heterorhabditidae are two independent monophyletic groups.

Phylogenetic relationships among currently recognised Heterorhabditis species were studied by Adams et al. (1998) based on 18S rDNA sequences. The relationships among taxa were well established, but lack of divergence within three lineages of sister taxa $(H$. marelatus $+H$. hepialius; H. indica $+H$. hawaiiensis; $H$. bacteriophora $+H$. argentinensis) suggested conspecificity. In support of this conclusion, a morphological re-examination has already led to synonymisation of $H$. marelatus and H. hepialius (Stock, 1997). The Heterorhabditis phylogeny of Liu et al. (1999) based on the ND4 mtDNA gene is broadly in agreement with that presented by Adams et al. (1998). The study of Adams et al. (1998) also indicated that the outgroup taxon Pellioditis was more closely related to Heterorhabditis than to Caenorhabditisand Steinernema.

Blaxter et al. (1998) also investigated the phylogenetic relationships of EPN in their molecular framework of the phylum Nematoda. Based on the analysis of $18 \mathrm{~S}$ rDNA sequences, they concluded heterorhabditidsand steinernematids do not share a common ancestry. Their study indicated that Heterorhabditis was associated with Strongylida and Steinernema was more closely related to Panagrolaimidae and Strongyloides. An ongoing phylogenetic study (Stock et al., unpubl.) based on a combined analysis of morphological and molecular characters (28S rDNA sequences) of 24 Steinernema and three Heterorhabditis species, suggests that the Steinernematidae constitute a paraphyletic group, and that members of the family Heterorhabditidae seem to have evolved within the Steinernematidae.

This summary of research on the phylogenetic relationships of EPN shows there is contradictory evidence on the relationships among these two families of EPN. While some authors indicated that heterorhabditids and steinernematids have evolved as two separate independent lineages (Liu et al., 1997; Adams et al., 1998; Blaxter et al., 1998), others suggested these two families are either sister taxa (Reid, 1994), or have evolved together (Stock et al., unpubl.). Incongruence between these studies may be attributed to many causes, including homoplasy, low resolving power of the techniques used, or use of tree building algorithms with different evolutionary assumptions. Therefore, rigorous examination of EPN species, with morphologicaland biological studies and sequencing of more genes, is encouraged to further assess robust phylogenetic relationships among this group of nematodes.

\section{Concluding remarks}

The impetus for research in EPN and their symbionts has come about because of their biological control potential, so much of the focus in EPN research has been on applied aspects relating to pest control (see Gaugler \& Kaya, 1990; Bedding et al. 1993 for reviews on these topics). However EPN and their symbionts are increasingly being viewed as an exciting subject for basic research in ecology, biodiversity, evolution, biochemistry and molecular genetics. The bacterial symbionts produce novel insecticidal toxins, antibiotics and exoenzymes, but many of these bacterial species and strains are still unexplored. The molecular interactions between EPN and their symbiont bacteria which enable the nematodes to package and transmit the bacteria are still largely unknown. EPN belong to the same family as $C$. elegans whose genome has been fully sequenced and annotated.Like C. elegans, their genome size is small (Grenier et al., 1997). EPN also have the advantage that they can be grown in vitro on lipid agar plates and are extremely prolific. They are easy to isolate from soil by baiting with susceptible insect larvae thus facilitating studies in biogeography and habitat preference (Bedding \& Akhurst, 1975). In the 10 years since the first international meeting on EPN at Asilomar (see proceedings edited by Gaugler and Kaya, 1990), much progress has been made in our understanding of the basic biology and genetics of EPN and their symbionts. We are now entering a new phase in which the tools of molecular genetics are being increasingly used to address a range of biological questions in EPN research. The knowledge gained from this endeavour should ensure that EPN will become even more effective biopesticides and should also ensure that EPN and their symbionts gain prominence as unique and intrinsically interesting biological systems.

\section{Acknowledgements}

Work in the authors' laboratories is supported by the European Community (STD-3 Programme Contracts TS3 CT94-0273 and FAIR CT 97-3116, AMB) and by the Eppley Foundation for Research (SPS).

\section{References}

ADAMS, B.J. (1998). Species concepts and the evolutionary paradigm in modern nematology. Journal of Nematology 30 , $1-21$. 
Adams, B.J., Burnell, A.M. \& Powers, T.O. (1998). A phylogenetic analysis of Heterorhabditis (Nemata: Rhabditidae) based on internal transcribed spacer 1 DNA sequence data. Journal of Nematology 30, 22-39.

Adamson, M.L. (1986). Modes of transmission and evolution of life histories in zooparasitic nematodes. Canadian Journal of Zoology 64, 1375-1384.

AkHuRst, R.J. (1986). Xenorhabdus nematophilus subsp. poinarii: its interaction with insect pathogenic nematodes. Systematic and Applied Microbiology 8, 142-147.

AkhuRst, R.J. (1987). Use of starch gel electrophoresis in the taxonomy of the genus Heterorhabditis (Nematoda: Heterorhabditidae). Nematologica 33, 1-9.

AkHuRst, R.J. (1993). Bacterial symbionts of entomopathogenic nematodes - the power behind the throne. In: Bedding, R., Akhurst, R. \& Kaya, H. (Eds). Nematodes and the biological control of insect pests. Melbourne, Australia, CSIRO Press, pp. 127-135.

Akhurst, R.J. \& Bedding, R.A. (1978). A simple crossbreeding technique to facilitate species determination in the genus Neoaplectana. Nematologica 24, 328-330.

AkHurst, R.J. \& Boemare, N.E. (1988). A numerical taxonomic study of the genus Xenorhabdus (Enterobacteriaceae) and proposed elevation of the subspecies of $X$. nematophilus to species. Journal of General Microbiology 134, 751-761.

Akhurst, R.J. \& Boemare, N.E. (1990). Biology and taxonomy of Xenorhabdus. In: Gaugler, R. \& Kaya, H.K. (Eds). Entomopathogenic nematodes in biological control. Boca Raton, FL, USA, CRC Press, pp. 75-90.

Bedding, R.A. \& Akhurst, R.J. (1975). A simple technique for the detection of insect parasitic rhabditid nematodes in the soil. Nematologica 21, 109-110.

Bedding, R., Akhurst, R. \& Kaya, H. (1993). Nematodes and the biological control of insect pests. Melbourne, Australia, CSIRO Press, $178 \mathrm{pp}$.

Bird, A.F. \& Akhurst, R.J. (1983). The nature of the intestinal vesicle in nematodes of the family Steinernematidae. International Journal of Parasitology 13, 599-606.

Blaxter, M.L., De Ley, P., Garey, J.R., LiU, L.X., Schheldeman, P., Vierstraete, A., Vanfleteren, J.R., MACKey, L.Y., Dorris, M., Frisse, L.M., VidA, J.T. \& Thом AS, W.K. (1998). A molecular evolutionary framework for the phylum Nematoda. Nature 392, 71-75.

BlEA KLEY, B.H. \& CHEN, X. (1999). Survival of insect pathogenic and human clinical isolates of Photorhabdus luminescens in previously sterile soil. Canadian Journal of Microbiology 45, 273-278.

Boag, B., Neilson, R. \& Gordon, S.C. (1992). Distribution and prevalence of the entomopathogenic nematode Steinernema feltiae in Scotland. Annals of Applied Biology 121, 355-360.

Boemare, N.E., Akhurst, R.J. \& Mourant, R.G. (1993). Deoxyribonucleic acid relatedness between Xenorhabdus spp. (Enterobacteriaceae), symbiotic bacteria of en- tomopathogenic nematodes, with a proposal to transfer Xenorhabdus luminescens to a new genus Photorhabdus gen. nov. International Journal of Systematic Bacteriology 43, 249-255.

Boemare, N. \& Givaudan, A. (1998). Pathogenicity of the symbionts. In: Simoes, N., Boemare, N. \& Ehlers, R.-U. (Eds). Pathogenicity of entomopathogenic nematodes versus insect defence mechanisms: impact on selection of virulent strains. Luxembourg, European Commission, ISBN 92-8280821-1, pp. 3-7.

Bowen, D., Rocheleau, T.A., Blackburn, M., AnDreev, O., Golubeva, E., Bhartia, R. \& FfrenchCONSTANT, R.H. (1998). Novel insecticidal toxins from the bacterium Photorhabdus luminescens. Science 280, 21202132.

Curran, J. \& Webster, J.M. (1989). Genotypic analysis of Heterorhabditis isolates from North Carolina. Journal of Nematology 21, 140-145.

Dix, I., Burnell, A.M., Griffin, C.T., Joyce, S.A., NuGENT, M.J. \& Downes, M.J. (1992). The identification of biological species in the genus Heterorhabditis (Nematoda: Heterorhabditidae) by cross-breeding second generation amphimictic adults. Parasitology 104, 509-518.

Dix, I., Koltai, H., Glazer, I. \& Burnell, A.M. (1994). Sperm competition in mated first generation hermaphrodite females of the HP88 strain of Heterorhabditis (Nematoda: Heterorhabditidae) and progeny sex ratios in mated and unmated females. Fundamental and Applied Nematology 17, 17-27.

ENDO, B.Y. \& NiCKLE, W.R. (1991). Ultrastructure of the intestinal epithelium, lumen and associated bacteria in $\mathrm{He}$ terorhabditis bacteriophora. Journal of the Helminthological Society of Washington 58, 202-212.

Farmer, J.J., Jorgensen, J.H., Grimont, P.A.D., AKhurst, R.J., Poinar, G.O. Jr, Pierce, G.V., Smith, J.A., CARGER, G.P., Wilson, K. \& HinkMAN-Brenner, F.W. (1989). Xenorhabdus luminescens (DNA hybridisation group 5) from human clinical specimens. Journal of Clinical Microbiology 27, 1594-1600.

Forst, S., Dowds, B., Boemare, N. \& Stackebrandt, E. (1997). Xenorhabdus and Photorhabdus spp.: bugs that kill bugs. Annual Review of Microbiology 51, 47-72.

Forst, S. \& NeALson, K. (1996). Molecular biology of the symbiotic-pathogenic bacteria Xenorhabdus spp. and Photorhabdus spp. Microbiological Reviews 60, 1-43.

FFrench-Constant, R. \& Bowen, D. (1999). Photorhabdus toxins: novel biological insecticides. Current Opinion in Microbiology 2, 284-288.

Fischer-Le SAuX, M., Arteaga-Hernández, E., MráčeK, Z. \& Boemare, N. (1999a). The bacterial symbiont Xenorhabdus poinarii (Enterobacteriaceae) is harbored by two phylogenetic related host nematodes: the entomopathogenic species Steinernema cubanum and 
Steinernema glaseri (Nematoda: Steinernematidae). FEMS Microbiology Ecology 29, 149-157.

Fischer-Le Saux, M., Viallard, V., Brunel, B., NorMAnd, P. \& Boemare, N. (1999b). Polyphasic classification of the genus Photorhabdus and proposal of new taxa: P. luminescens subsp. luminescens subsp. nov., P. luminescens subsp. akhurstii subsp. nov., P. luminescens subsp. laumondii subsp. nov., $P$. temperata sp. nov., $P$. temperata subsp. temperata subsp. nov. and $P$. asymbiotica sp. nov. International Journal of Systematic Bacteriology 49, 1645-1656.

Garcia del Pino, F. \& Palomo, A. (1996). Natural occurrence of entomopathogenic nematodes (Rhabditida: Steinernematidae and Heterorhabditidae) in Spanish soils. Journal of Invertebrate Pathology 68, 84-90.

Gardner, S.L., Stock, S.P. \& KAyA, H.K. (1994). A new species of Heterorhabditis from the Hawaiian islands. Journal of Parasitology 80, 100-106.

Gaugler, R. \& KaYA, H.K. (1990). Entomopathogenic nematodes in biological control. Boca Raton, FL, USA, CRC Press, 365 pp.

Götz, P., BomAn, A. \& BowmAn, H.G. (1980). Interactions between insect immunity and an insect-pathogenic nematode with symbiotic bacteria. Proceedings of the Royal London Society 212, 333-350.

Grenier, E., Bonifassi, E., Abad, P. \& Laumond, C. (1996). Use of species specific satellite DNAs as diagnostic probes in the identification of Steinernematidae and $\mathrm{He}$ terorhabditidae entomopathogenic nematodes. Parasitology 113, 483-489.

Grenier, E., Catzeflis, F.M. \& Abad, P. (1997). Genome sizes of the entomopathogenic nematodes Steinernema carpocapsae and Heterorhabditis bacteriophora (Nematoda: Rhabditida). Parasitology 114, 497-501.

Griffin, C.T., Dix, I., Joyce, S.A., Burnell, A.M. \& DOWNES, M.J. (1999). Isolation and characterisation of Heterorhabditis spp. (Nematoda: Heterorhabditidae) from Hungary, Estonia and Denmark. Nematology 1, 321-332.

Griffin, C.T., Downes, M.J. \& Block, W. (1990). Tests of Antarctic soils for insect parasitic nematodes. Antarctic Science 2, 221-222.

Griffin, C.T., Joyce, S.A., Dix, I., Burnell, A.M. \& DownES, M.J. (1994). Characterisation of the entomopathogenic nematode Heterorhabditis (Nematoda: Heterorhabditidae) from Ireland and Britain by molecular and crossbreeding techniques, and the occurrence of the genus in these islands. Fundamental and Applied Nematology 17, 245-253.

GrifFin, C.T., Moore, J.F. \& Downes, M.J. (1991). Occurrence of insect-parasitic nematodes (Steinernematidae, Heterorhabditidae) in the Republic of Ireland. Nematologica 37, 92-100.

Hominick, W.M., Briscoe, B.R., Del Pino F.G., Heng, J., Hunt, D.J., Kozodoy, E., MrÁČeK, Z., Nguyen, K.B., Reid, A.P., Spiridonov, S., Stock, P., Sturhan, D., Waturu, C. \& Yoshida, M. (1997).
Biosystematics of entomopathogenic nematodes: current status, protocols and definitions. Journal of Helminthology 71, 271-298.

Hominick, W.M., Reid, A.P., Bohan, D.A. \& Briscoe, B.R. (1996). Entomopathogenic nematodes: biodiversity, geographical distribution and the convention on biological diversity. Biocontrol Science and Technology 6, 317-331.

Hominick, W.M., Reid, A.P. \& Briscoe, B.R. (1995). Prevalence and habitat specificity of steinernematid and heterorhabditid nematodes isolated during soil surveys of the UK and the Netherlands. Journal of Helminthology 69, 2732.

JAROZ, J. (1996). Ecology of antimicrobials produced by bacterial associates of Steinernema carpocapsae and Heterorhabditis bacteriophora. Parasitology 112, 545-552.

JARrett, P.D., Ellis, D. \& Morgan, J.A.W. (1997). World intellectual property Patent GB 97/02284.

JohnigK, S.-A. \& EhLERS, R.-U. (1999). Juvenile development and life cycle of Heterorhabditis bacteriophora and H. indica (Nematoda: Heterorhabditidae). Nematology 1, 251-260.

Joyce, S.A., Griffin, C.T. \& Burnell, A.M. (1994a). The use of isoelectric focusing and polyacrylamide gel electrophoresis of soluble proteins in the taxonomy of the genus Heterorhabditis (Nematoda: Heterorhabditidae) Nematologica 40, 601-612.

Joyce, S.A., Burnell, A.M. \& Powers, T.O. (1994b). Characterisation of Heterorhabditis isolates by PCR amplification of segments of mtDNA and rDNA genes. Journal of Nematology 26, 260-270.

Kaya, H.K. \& Gaugler, R. (1993). Entomopathogenic nematodes. Annual Review of Entomology 38, 181-206.

KAYA, H.K \& STOCK, S.P. (1997). Techniques in insectnematology. In: Lacey, L.A. (Ed.). Manual of techniques in insect pathology. San Diego, CA, USA, Academic Press, pp. 281324.

LIU, J. \& BERRY. R.E. (1995). Natural distribution of entomopathogenic nematodes (Rhabditida: Steinernematidae and Heterorhabditidae) in Oregon soils. Environmental Entomology 24, 159-163.

LIU, J. \& BERRY, R.E. (1996a). Heterorhabditis marelatus n.sp. (Rhabditida: Heterorhabditidae) from Oregon. Journal of Invertebrate Pathology 67, 48-54.

LIU, J. \& BERRY, R.E. (1996b). Phylogenetic analysis of the genus Steinernema by morphological characters and randomly amplified polymorphic DNA fragments. Fundamental and Applied Nematology 19, 463-469.

Liu, J., Berry, R.E. \& Blouin, M.S. (1999). Molecular differentiation and phylogeny of entomopathogenic nematodes (Rhabditida: Heterorhabditidae) based on ND4 gene sequences of mitochondrial DNA. Journal of Parasitology 85, 709-715.

LiU, J., Berry, R.E. \& Moldenke, A.F. (1997). Phylogenetic relationships of entomopathogenic nematodes (He- 
terorhabditidae and Steinernematidae) inferred from partial 18S rRNA gene sequences. Journal of Invertebrate Pathology 69, 246-252.

Morgan, J.A.W., Kuntzelmann, V., Travenor, S., Ousley, M.A. \& Winstanley, C. (1997). Survival of Xenorhabdus nematophilus and Photorhabdus luminescens in water and soil. Journal of Applied Microbiology 83, 655670.

MrÁČEK, Z. (1977). Steinernema kraussei, a parasite of the body cavity of the sawfly, Cephalcia abietis in Czechoslovakia. Journal of Invertebrate Pathology 30, 87-94.

MrÁČEK, Z. (1994). Steinernema kraussei (Steiner 1923) (Nematoda: Rhabditida: Steinernematidae): redescription of its topotype from Westphalia. Folia Parasitologica 41, 59-61.

MráčeK, Z., Becvar, S. \& Kindlmann P. (1999). Survey of entomopathogenic nematodes from the families Steinernematidae and Heterorhabditidae (Nematoda: Rhabditida) in the Czech Republic. Folia Parasitologica 46, 145-148.

NGUYen, K.B. \& SMART, G.C. JR. (1988). A new steinernematid from Uruguay. Journal of Nematology 22, 187.

NGUYEN, K.B. \& SMART, G.C. JR. (1996). Identification of entomopathogenic nematodes in the Steinernematidae and Heterorhabditidae (Nemata: Rhabditida). Journal of Nematology 28, 286-300.

POINAR, G.O. JR. (1967). Description and taxonomic position of the DD136 nematode (Steinernematidae, Rhabditoidea) and its relationship to Neoaplectana carpocapsae Weiser. Proceedings of the Helminthological Society of Washington 34, 199-209.

PoINA R, G.O. JR. (1979). Nematodes for the biological control of insects. Boca Raton, FL, USA, CRC Press, 227 pp.

POINAR, G.O. JR. (1981). The natural history of nematodes. Englewood Cliffs, NJ, USA, Prentice Hall Inc, 323 pp.

POINAR, G.O. JR. (1990). Taxonomy and biology of Steinernematidae and Heterorhabditidae. In: Gaugler, R. \& Kaya, H.K. (Eds). Entomopathogenic nematodes in biological control. Boca Raton, FL, USA, CRC Press, pp. 23-61.

POINAR, G.O. JR. (1993). Origins and phylogenetic relationships of the entomophilic rhabditids Heterorhabditis and Steinernema. Fundamental and Applied Nematology 16, 333338.

Poinar, G.O. JR. \& Kozodoi, E.M. (1988). Neoaplectana glaseri and $N$. anomali: sibling species or parallelism. Revue de Nématologie 11, 13-19.

PoinAR, G.O. JR. \& Thomas, G.M. (1967). The nature of Achromobacter nematophilus as an insect pathogen. Journal of Invertebrate Pathology 9, 510-514.

REID, A.P. (1994). Molecular taxonomy of Steinernema. In: Burnell, A.M., Ehlers, R.-U. \& Mason, J.P. (Eds). Genetics of entomopathogenic nematode-bacterium complexes. Luxembourg, European Commission, ISBN 92-826-7912-8, pp. 4958.

ReID, A.P. \& HoMINICK, W.M. (1993). Cloning of rDNA repeat unit from British entomopathogenic nematode (Stein- ernematidae) and its potential for species identification. Parasitology 107, 529-536.

Reid, A.P., Hominick, W.M. \& BRiscoe, B.R. (1997). Molecular taxonomy and phylogeny of entomopathogenic nematode species (Rhabditidae: Steinernematidae) by RFLP analysis of the ITS region of the ribosomal DNA repeat unit. Systematic Parasitology 37, 187-193.

Simõ ES, N. (1998). Pathogenicity of the complex Steinernema carpocapsae-Xenorhabdus nematophilus: molecular aspects related with virulence. In: Simoes, N., Boemare, N. \& Ehlers, R.-U. (Eds). Pathogenicity of entomopathogenic nematodes versus insect defence mechanisms: impact on selection of virulent strains. Luxembourg, European Commission, ISBN 92-828-0821-1, pp. 73-84.

STEINER, G. (1923). Aplectana kraussei n. sp. Eine in der Blattwespe Lyda sp. parasitierende Nematodenform, nebst Bemerkungen über das Seitenorgan der parasitischen Nematoden. Zentrablatt für Bakteriologie, Parasitenkunde, Infektionskrankheitenund Hygiene, Abteilung 2 59, 14-18.

STEINER, W.A. (1994). Distribution of nematopathogenic nematodes in the Swiss Alps. Revue Suisse de Zoologie 103, 439-452.

STоск, S.P. (1997). Heterorhabditishepialius Stock, Strong \& Gardner, 1996 a junior synonym of $H$. marelatus Liu \& Berry, 1996 (Rhabditida: Rhabditidae) with a redescription of the species. Nematologica 43, 455-463.

STOCK, S.P., STRONG, D.R. \& GARDNER, S.L. (1996). Identification of Heterorhabditis (Nematoda: Heterorhabditidae) from California with a new species isolated from the larvae of the ghost moth Hepialis californicus (Lepidoptera: Hepialidae) from the Bodega Bay Natural Reserve. Fundamental and Applied Nematology 19, 585-592.

Stock, S.P., Choo, H.Y. \& Kaya, H.K. (1997). An entomopathogenic nematode, Steinernema monticolum sp. n. (Nematoda: Steinernematidae) from Korea with a key to other species of the genus. Nematologica 43, 15-29.

StOCK, S.P., PryoR, B.M. \& KAYA, H.K. (1999). Distribution of entomopathogenic nematodes (Steinernematidae and Heterorhabditidae) in natural habitats in California, USA. Biodiversity and Conservation 8, 535-549.

Stock, S.P., Mráček, Z. \& Webster, J.M. (2000). Morphological variation between allopatric populations of Steinernema kraussei (Steiner, 1923) (Rhabditida, Steinernematidae). Nematology 2 (in press).

Strauch, O., Stoessel, S. \& Ehlers, R.-U. (1994). Culture conditions define automictic or amphimictic reproduction in entomopathogenic rhabditid nematodes of the genus Heterorhabditis. Fundamental and Applied Nematology 17, 575-582.

Stuart, R.J. \& Gaugler, R. (1994). Patchiness in populations of entomopathogenic nematodes. Journal of Invertebrate Pathology 64, 39-45.

Sturhan, D. (1999). Prevalence and habitat specificity of entomopathogenic nematodes in Germany. In: Gwynn, R.L., 
Smits, P.H., Griffin, C.T., Ehlers, R.-U., Boemare, N. \& Masson, J.P. (Eds). Entomopathogenic nematodes, application and persistence of entomopathogenic nematodes. Luxembourg, European Commission, ISBN 92-828-6887-7, pp. 123-132.

Sudhaus, W. (1993). Die mittels symbiontischer Bakterien entomopathogenen Nematoden Gattungen Heterorhabditis and Steinernema sind keine Schwestertaxa. Verhandlungen der Deutschen Zoologischen Gesellschaft 86, 146.

Sudhaus, W. \& Schulte F. (1988). Rhabditis (Rhabditis) necromena sp. n. (Nematoda: Rhabditidae) from South Australian diplopoda with notes on its siblings $R$. myriophila Poinar, 1986 and R. caulleryi Maupas, 1919. Nematologica $35,15-24$.

SzÁllás, E., Koch, E., Fodor, A., Burghardt, J., Boss, O., Szentirmai, A., Nealson, K.H. \& Stakebrandt, E. (1997). Phylogenetic evidence for the taxonomic hetero- geneity of Photorhabdus luminescens. Journal of Systematic Bacteriology 47, 402-407.

Thomas, G.M. \& Poinar, G.O. JR. (1979). Xenorhabdus gen. nov., a genus of entomopathogenic and nematophilic bacteria of the family Enterobacteriaceae.InternationalJournal of Systematic Bacteriology 29, 352-360.

WANG, J. \& BEDding, R.A. (1996). Population development of Heterorhabditis bacteriophora and Steinernema carpocapsae in the larvae of Galleria mellonella. Fundamental and Applied Nematology 19, 363-367.

Wilkinson, T.L. \& HAY, D.B. (1997). Symbiotic interactions in entomopathogenic nematodes. Symbiosis 22, 9-19.

Yoshida, M., Reid, A.P., Briscoe, B.R. \& Hominick, W.M. (1998). Survey of entomopathogenic nematodes (Rhabditida: Steinernematidae and Heterorhabditidae) in Japan. Fundamental and Applied Nematology 21, 185-198. 